UDC 330.8

DOI: 10.18523/2519-4739.2021.6.1.3-7

P. Adair, O. Nezhyvenko

\title{
TUGAN-BARANOVSKY'S BUSINESS CYCLE THEORY AND FRENCH ECONOMISTS: INSPIRATION AND LEGACY
}

\begin{abstract}
The purpose of the paper is to emphasize the contribution of Mykhaylo Ivanovych Tugan-Baranovsky to Business Cycle theory and its legacy among French economists.

Tugan-Baranovsky (1864-1919), a prominent Ukrainian economist was a cycle theorist who was inspired by some French or francophone economists whose language he mastered. His theory of industrial crises proved influential upon some major economists during the first quarter of the twentieth century until the Great Depression, from Spiethoff to Hayek and Keynes.

We present both the history and analytical content of industrial crises in the French version of TuganBaranovsky's masterpiece. We provide an overview of Tugan-Baranovsky's intellectual legacy as for his French-speaking followers, namely, Lescure, Aftalion, Robertson and Bouniatian. The ebb and tide of Tugan-Baranovsky's influence can be understood throughout two episodes: the shift from real to monetary cycles in the interwar period and the revival of real business cycles alongside New Classical Economics in the 1980s, which proves relevant again in the context of the current Great Lockdown Recession.
\end{abstract}

Keywords: history of macroeconomic analysis, industrial crises, real cycles, Ukrainian thinking.

\section{JEL classification: B14, E32, N13}

Introduction. Mykhaylo Ivanovych TuganBaranovsky (1864-1919), who died a century ago, deserves a celebration and an evaluation. He has enjoyed a scholarly interest since the collapse of real socialism in the early 1990s and the claim of intellectual Ukrainian inheritance. He is a prominent Ukrainian Economist, a cycle theorist inspired by some French or francophone economists whose language he mastered; his theory of crises proved influential upon some major economists during the first quarter of the twentieth century until the Great Depression, from Spiethoff to Hayek and Keynes, and upon French (speaking) economists such as Lescure, Aftalion, Robertson and Bouniatian.

Tugan-Baranovsky (1894) designed the first economic theory of the real business cycle, based on the disproportionate nature of capital goods vs. consumption goods industries, the overinvestment in the capital goods industry generating periodic recessions. He inspired European economists such as Arthur Spiethoff (1873-1957) from the third German Historical School, Gustav Cassel (1866-1945) in Sweden who did not quote him, Denis Holmes Robertson (1890-1963) in England, Michal Kalecki (1899-1970) in Poland and Friedrich-August Hayek (1899-1992) in Austria. It is noteworthy that Hayek was probably the last economist in that period to emphasize structural patterns and he paid tribute to Tugan-Baranovsky in this respect (Hayek, 1931, p. $103 ; 1941$, p. 426) alongside non-monetary theorists such as Lescure and Aftalion.

Tugan-Baranovsky was a major scholar in the business cycle theory since 1901, with the German translation of his book first published in Russian (1894). The first stage of this theory was gradually designed according to the historical and analytical approach that was prominent in the late $19^{\text {th }}$ and early beginning of the $20^{\text {th }}$ century. In this respect, Wesley Clair Mitchell's Business Cycles (Mitchell, 1913) stands as a benchmark of that stage, which remain prominent until "the years of high theory" (Shackle, 1967) started in the 1930s a new stage wherein business cycles would be built upon modelling and econometrics.

Tugan-Baranovsky's inspiration and analysis of his business cycle theory. Tugan-Baranovsky theory of crises was first published in 1894; a revised Russian version was published in 1900 and a third Russian version was published in 1914 (Barnett, 2005, pp. 48-55). It enjoyed a German edition in 1901 as well as a French edition in 1913. No English version has been published so far. A partial English translation was provided from the Russian edition in 1954 (Tugan-Baranovsky, 1914) and from the German edition (Hagemann, 2002).

The French version (Tugan-Baranovsky, 1913) is the translation of the second Russian edition, revised and expanded by Tugan-Baranovsky, which 
covers the two world crises of 1900 and 1907. The book comprises three parts: the first presents the history of crises, the second is devoted to the theory of crises and the third examines the social consequences such as pauperism and crime that we do not discuss here. The book exposes a "new theory of crises that is a synthesis of the doctrines of classical economics and of the exposition given by Marx in the second volume of Capital" (TuganBaranovsky, 1913, preface, p. 5).

Almost a century of industrial crises: an historical overview. In the first part, five chapters cover the crises of 1820 to 1910 . Tugan-Baranovsky dates from 1821 the first periodic industrial crisis (p. 34) and notes a change in context: from 1830 to 1850 , the English industry suffers tight markets and lower prices, while the period from 1850 to 1873 was a period of favorable economic conditions; finally, 1875 marks the end of English industrial supremacy.

The substitution of large-scale production for the small and of the machine for manual labor has led to an enormous increase in the productivity of labor (p. 7).

The fundamental law of capitalist development manifests itself: the more the technique progresses, the more the consumption goods diminish in importance with regard to the means of production (p. 26).

The cycle consists of three stages: prosperity, industrial crisis, stagnation or depression. Each industrial crisis was preceded by the same market situation, both in the money market and in the commodities market. Each period of prosperity ended with an industrial crisis, followed by a more or less long period of stagnation in business (p. 40).

The fall in prices, at the same time, the cause and the consequence of the decline in production, constitutes an industrial crisis (pp. 73-74).

Industrial crises dissociated from financial crises until 1870. Peel's banking reform in 1844 completely failed to prevent the recurrence of crises, or to mitigate economic repercussions. This results from the completely false idea that crises are caused by the defective organization of credit institutions. However, in 1870-1880, fluctuations in the industry depend on credit fluctuations (pp. 141-142).

Tugan-Baranovsky made a distinction between several periods of time pointing out that before 1823 , crises were exogenous, whereas they became endogenous. He also made a distinction between industrial crises due to excess supply over demand, monetary crises (due to cash shortage) and credit crises (credit crunch).

Tugan-Baranovsky (1913) observes that crises are a recurring phenomenon (i.e. cycles) within an interval from seven to eleven years. The crises of 1825,1836 , and 1847 are divided by eleven intervals; but the crisis of 1857 - in 10 years and then in $1866-$ in 9 years. The further industrial depressions lasted seven years (1873-1879); then six years (1882-1887); five years (1891-1895); three years (1901-03) and two years (1908-09). Obviously, the industrial cycle began to shorten. On the other hand, the latter decade has two periods of depression.

Hence, Tugan-Baranovsky's stylized facts applied to cycles would be consistent with Kaldor's (1957) stylized facts focusing on historical growth constants identified by the long-term average, whose cyclical fluctuations break the trend.

There is a close connection between the phases of the cycle and the fluctuation in the demand for iron, a major component of fixed capital.

Analytics: From a theory of markets towards a theory of production. Tugan's endogenous, nonmonetary and supply side cycle theory. Tugan clearly states what his theory of industrial crises is not, rejecting the three following explanations: (i) exogenous theories of production, e.g. harvests depending on periodic sunspots (Jevons, 1884), (ii) theories of credit and monetary circulation (Laveleye, 1865), and the fall in commodity prices (Juglar, 1889), (iii) theories of income distribution whereby crises come from insufficient demand (Sismondi, 1819). Tugan stands on the supply side endorsing the "law of markets" that Jean-Baptiste Say (1767-1832) coined in 1803 (Say, 1854).

A Keynesian tale. Hansen ([1927], 1951, note, p. 277) sketches a paraphrase of Tugan's French version (1913) although his interpretation is mostly shaped in Wicksell and Keynes' analytical framework. Hence, he overlooks Tugan's own analytical framework founded on a reinterpretation of Marx's reproduction schemes.

The demand for fixed capital drives the demand for other goods from other industries, suggesting a multiplier effect. The higher the propensity to save, the greater the amplitude of fluctuations (Hansen, 1951, p. 300). The mechanical metaphor of the steam engine illustrates the alternation of prosperity and depression. The accumulation of capital plays the role of steam in the cylinder pushing the piston. Hence, once loanable funds transform into investment, they give birth to prosperity and growth is set into motion. Conversely, when the steam is exhausted, the crisis occurs, driving toward stagnation or depression.

However, Hansen challenges the metaphor: is it due to a push from idle loanable funds according to Tugan-Baranovsky, or a pull from technology according to Spiethoff? Bazhal (2013) supports this latter quasi-Schumpeterian pull explanation. However, it seems to run against Tugan's endogenous approach and it needs to be backed by the 
distinction coined by Frish (1933) between impulse (exogenous?) and propagation (endogenous).

Last, on the analytical ground, although not the empirical ground, Tugan-Baranovsky (1913) contends that the mechanism of crises is uniform. Every crisis is preceded by an expansion of production and increase in commodity prices; then commodity prices fall and the succession of changes begins in the circulation of money and credit and ends with the complete destruction of credit.

Tugan-Baranovsky's (1913) contribution to the business cycle theory can be interpreted as a vertical maladjustment between the structure of production and the decision of consumers (Haberler, 1943, p. 72). In this respect, Tugan-Baranovsky belongs to mainstream non-monetary business cycle theory discrepancy between savings and investment, according to which it is savings (loanable funds) or supply and not investment demand that triggers the cycle downswing (Kim, 1988).

Marxian reproduction and accumulation. Tugan-Baranovsky's theory of crises has two components: a theory of markets, defining the condition enabling enlarged reproduction to take place, and a theory of production encapsulating crises wherein which any disruption of equilibrium is amplified and extended to the entire economy, giving birth to periodic fluctuations.

The analytics of crises should start with a theory of markets including Quesnay's Tableau Economique, Say's law and especially the Marxian schemes of reproduction, whereas the theory of production is based on the accumulation and depletion of loanable funds.

A major difference between Tugan's and Marx's interpretation of crises is that Tugan takes equilibrium as the norm from which recurring periodic crises deviate, whereas Marx considers crises as the necessary corrective to the systematic and necessary breaches of equilibrium (Besoni, 2006).

Legacy. Reijnders (1998) and Barnett (2001) have provided an exhaustive account of the influence of The Industrial Crises upon later economists. As a pupil of Tugan-Baranovsky in Saint Petersburg and the designer of the 'long waves', Nikolay Kondratiev (1892-1938) stands first among these economists. In 1926, he refers to Lescure and Aftalion, who conversely never refer to him. The first French economist quoting Kondratieff was Marjolin in 1938 (Escudier, 1993).

Tugan-Baranovsky's intellectual legacy includes French-speaking economists, Jean Lescure and Albert Aftalion, as well as the English and francophone economist Dennis Holme Robertson; later on Mentor Bouniatian adds to this group. All these economists advocate a real (i.e. non-monetary) approach to the cycle, based on over-investment.
Lescure on the endogenous "real" cycle. Jean Lescure (1882-1947) stands first among the French followers, the most enthusiastic (Lescure, 1906, p. 6), but not a faithful one: Lescure (1912; 1906, 3rd ed. 1923 ) refutes both Say's law of supply and demand.

Lescure's focus on long-term movements (25 years) - an alternation between the rise and decline in the prices of goods, factors and incomes is not consistent with the measurement of cycles gauged by Juglar (1889) and Tugan-Baranovsky (1894).

All crises have one essential feature: the progress in one or two rapidly expanding industries is interrupted by a rapid rise in the cost of production or through an insufficient demand for their productsmost often from both factors. (Lescure, 1932).

Lescure (1933) rejects the triggering role of speculation and credit in the occurrence of crises defended by Juglar (1862). Crises come from the variation in the rate of profit and the paralysis of entrepreneurship.

Aftalion and the structural pattern of crises. Albert Aftalion (1874-1956) completed his theory of cycles after Tugan-Baranovsky. Aftalion (1913) quotes twelve times the German edition (TuganBaranovsky, 1901).

Aftalion (1913) follows the comparative approach of Juglar (1862, 1889) and compares the index numbers from 1847 to 1910 as for France, Germany, England and the USA, whereas Tugan-Baranovsky's focus is upon England. According to Aftalion (1913, p. 10), the crisis is only one of the moments of the periodic cycle, a moment that remains unspecified by Tugan-Baranovsky (Robertson, 1914).

Alongside Lescure, Aftalion sticks to Juglar's methodological principles, briefly defined as the statistical verification method of the theory.

According to Aftalion, the crisis is endogenous and manifests itself in the price decline, the fluctuations in credit being the consequence and not the cause of such decline. The mechanism of overinvestment is based on the accelerator principle, and the gap between the capital goods industry and that of consumer goods inspires from Sismondi (1819), an explanation Tugan-Baranovsky denies.

Robertson on Aftalion and Tugan-Baranovsky. Dennis Holme Robertson (1890-1963) cites TuganBaranovsky (1913) six times, while quoting Aftalion ten times (Robertson, 1915).

Although they still use the concept of "crises", both Aftalion and Robertson are in tune with the business cycle concept coined by Mitchell (1913), which comprises several successive phases that constitute an endogenous phenomenon.

Bouniatian on overproduction and English crises. Mentor Bouniatian (1877-1969), a refugee 
in France, claimed priority over Aftalion for stating the accelerator principle from 1907 in the German version of his book, which was translated in Russian in 1915 and French (Bouniatian, 1922).

Like Tugan-Baranovsky, he defends a realcycle approach, whereby credit is passive and capital goods industries suffer more during the depression phase than consumer goods industries. In contrast with Tugan-Baranovsky, Bouniatian (1922) explains in the first part of the book that overinvestment necessarily leads to overproduction. The second part of the book provides a history of economic crises in England from 1640 to 1840, whereas Tugan-Baranovsky covered the entire $19^{\text {th }}$ century.

Ebb and tide: shifting from real to monetary cycles and back again. Keynes (1930, pp. 100-101) quoted Tugan-Baranovsky among the most original economists, but claimed that demand and money play little role in Tugan-Baranovsky's theory of industrial crises.

Keynesian influence started spreading with the Great Depression; the General Theory provided the link between the theory of demand and economic depression.
The demise of Keynesian supremacy parallels the development of New Classical Economics, among which Robert Lucas (1972, 1980) made a major contribution based on the market clearing assumption, which is deeply rooted in Say's law, and real business cycles driven by real or monetary (exogenous) shocks. Interestingly, Say's law is the basis of Tugan-Baranovsky's theory, although his real business cycles are endogenous.

Conclusion. As much as England was the benchmark of capitalism, Tugan-Baranovsky's focus upon British industrial crises in the long run provides an in-depth empirical investigation over the $19^{\text {th }}$ century. However, Tugan-Baranovsky overlooks the fruitfulness of a comparative approach, such as the one Mitchell (1913) designed.

Tugan-Baranovsky designed a theory of crises, built upon analytics, which were missing in the contribution of Juglar $(1862,1882)$. He was a pioneer of the theory of endogenous real cycles, as Mitchell (1913) points out. Of course, Tugan-Baranovsky did not forge the multiplier, he did neither distinguish impulse from propagation, nor did he link real and monetary cycles. On these crucial issues, room enough was left for his successors.

\section{References}

Aftalion, A. (1913). Les crises périodiques de surproduction. 2 vol. Paris: Marcel Rivière.

Allisson, F. (2015). Value and Prices in Russian Economic Thought. A journey inside the Russian synthesis, 1890-1920. Routledge.

Barnett, V. (2001). Tugan-Baranovsky as a pioneer of trade cycle analysis. Journal of the History of Economic Thought, 23(4), 443-466.

Barnett, V. (2005). A History of Russian Economic Thought. London: Routledge.

Bazhal, I. (2013). Innovation theory of business cycles and economic growth. MPRA Paper No. 53688.

Besoni, D. (2006). Marxism Gone Mad: Tugan-Baranovsky on crises, their possibility and their periodicity. Review of Political Economy, 18(2), 147-171.

Bouniatian, M. (1922). Les crises économiques: Essai de morphologie et théorie des crises économiques périodiques et de théorie de la conjoncture économique. Trad. franç. Paris: Giard. (1907). Studien zur Theorie und Geschichte der Wirtschaftskrisen.

Cassel, G. (1918). Theory of the Social Economy. New York: Augustus M. Kelley, 1967. English translation of the $5^{\text {th }}$ edition, 1932. Book IV, pp. 533-652.

Escudier, J.-L. (1993). Kondratieff et l'histoire économique française ou la rencontre inachevée. Annales. Economies, Sociétés, Civilisations, 48(2), 359-383.

Frisch, R. (1933). Propagation problems and impulse problems in dynamic economics. In Economic Essays in Honour of Gustav Cassel (pp. 171-205). Routledge, 1967.

Haberler, G. (1937). Prosperity and Depression. $2^{\text {nd }}$ ed. 1943 , League of Nations, New York.

Hansen, A. H. (1927). Business-Cycle Theory: Its Development and Present Status. Boston: Ginn and Cy. Expanded in Hansen, A. H. (1951), part III, Ch. 16.

Hansen, A. H. (1951). Business Cycles and National Income. London: Allen \& Unwin.
Hayek, F. A. von. (1931). Prices and Production. Ludwig von Mises Institute, 2008.

Hayek, F. A. von. (1941). The Pure Theory of Capital. Chicago: The University of Chicago Press, 1952.

Jevons, W. S. (1884). Investigations in Currency and Finance. London, Macmillan. Articles: "The Solar Period and the Price of Corn," "The Periodicity of Commercial Crises," "Commercial Crises and Sun-spots."

Juglar, C. (1862). Des crises commerciales et de leur retour périodique en France, en Angleterre et aux États-Unis. Guillaumin. Gallica. $2^{\text {nd }}$ ed. 1889 , Open edition ENS, Lyon, 2014.

Kaldor, N. (1957). A Model of Economic Growth. Economic Journal, 67(268), 591-624.

Kalecki, M. (1967). The problem of Effective demand with TuganBaranovsky and Rosa Luxembourg. In Kalecki, M. (1970). Selected Essays on the Dynamics of the Capitalist Economy 1933-1970 (pp. 146-164). Cambridge University Press.

Keynes, J. M. (1930). A Treatise on Money. Vol. 2. The Applied Theory of Money. London: Harcourt \& Brace.

Kim, K. (1988). Equilibrium business cycle theory in historical perspective. Cambridge.

Kondratieff, N. (1923). M. I. Tugan-Baranovsky (The Main Features of His Scientific Worldview). In Grinin, L., Devezas, T., \& Korotayev, A. (Eds.). (2014). Kondratieff Waves: Juglar Kuznets - Kondratieff (pp. 396-407). Volgograd: 'Uchitel' Publishing House.

Laveleye, E. de. (1865). Le Marché Monétaire et ses Crises depuis cinquante ans. Paris: Guillaumin.

Lescure, J. (1906). Des crises générales et périodiques de surproduction. Paris: Domat-Montchrestien.

Lucas, R. E. (1972). Expectations and the neutrality of money. Journal of Economic Theory, 4(2), 103-124.

Lucas, R. E. (1980). Methods and Problems in Business Cycle Theory. Journal of Money, Credit and Banking, 12(4), 696-715. 
Mitchell, W. C. (1913). Business Cycles. University of California Press.

Reijnders, J. (1998). Tugan-Baranowsky's breakthrough in business cycle theory. In Glombowski, J., Gronert, A., \& Plasmeijer, H. W. (Eds.), History of Continental Economic Thought (pp. 211-238). Metropolis, Marburg.

Robertson, D. H. (1915). A Study of Industrial Fluctuation. London: P.S. King.

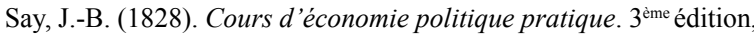
1854. In Tiran, A. (éd.), Euvres économiques complètes, Vol. 2, Economica, 2010.

Shackle, G. L. S. (1967). The years of high theory: Invention and Tradition in Economic Thought 1926-1939. Cambridge University Press (1983).

Sismondi, J. C. L. Simonde de. (1819). Nouveaux principes d'économie politique. Seconde édition, 1827. In Bridel, P., Dal Degan, F., Eyguesier, N. (éds), Euvres économiques complètes, Vol. 5, Economica, 2015

Spiethoff, A. (1902). Vorbemerkungen zu einer Theorie der Überproducktion. Schmoller Jahrbuch für Gesetzgebung,
Verwaltung und Volkswirtschaft, 26, Duncker und Humblot, p. 721 .

Spiethoff, A. (1903). Die Krisentheorien von M. v. Tugan-Baranovsky und L. Pohle. Schmoller Jahrbuch für Gesetzgebung, Verwaltung und Volkswirtschaft im Deutschen Reich, 27, 331-360.

Tugan-Baranovsky, M. (1894). Promyshlennye kryzisy v sovremennoi Anglii. St. Petersburg. French translation $2^{\text {nd }}$ ed. Les crises industrielles en Angleterre. 1913. Paris: Giard \& Brière.

Tugan-Baranovsky, M. I. (1914). Periodic Industrial Crises. A History of British Crises. Excerpts from Part II, "The Theory of Crises." The Annals of the Ukrainian Academy of Arts and Sciences in the US, 3(9), 745-802. 1954.

Tugan-Baranovsky, M. I. (1901). Studien zur Theorie und Geschichte der Handelskrisen in England. Jena: Gustav Fischer. In Hagemann, H. (Ed.) (2002). Business Cycle Theory. Selected Texts 1860-1939, Vol. II: Structural Theories of the Business Cycle (pp. 1-44). London: Pickering \& Chatto.

Wicksell, K. (1906). Lectures in Political Economy. Vol. 2. Money. Routledge, English translation, 1935.

Адер Ф., Неживенко О. В.

\section{ТЕОРІЯ БІЗНЕС-ЦИКЛУ ТУГАН-БАРАНОВСЬКОГО І ФРАНЦУЗЬКІ ЕКОНОМІСТИ: НАТХНЕННЯ ТА СПАДЩИНА}

Метою статті $€$ аналіз внеску Михайла Івановича Туган-Барановського в теорію ділового циклу та його спадщини серед французьких економістів відповідно до нових реалій сьогодення.

Туган-Барановський (1864-1919), видатний український економіст, з одного боку, був теоретиком економічних циклів, який надихався від деяких французьких або франкомовних економістів, адже знав французьку мову. 3 іншого боку, його теорія промислових криз мала вплив на багатьох визначних економістів протягом першої чверті XX століття і до Великої депресії - від Шпітгофа до Хайєка і Кейнса.

Туган-Барановський був одним із перших, хто помітив, що кризи є повторюваними і відбуваються циклічно з інтервалами від семи до одинадцяти років. Згідно з його теорією, економічний цикл складається 3 трьох етапів: процвітання, промислова криза, стагнація або депресія. Кожній промисловій кризі передували однакові умови на ринку, як на грошовому, так і на товарному. Крім того, ознакою промислової кризи є падіння цін, одночасно будучи причиною та наслідком спаду виробництва. Туган-Барановський також зауважив, що до 1823 року кризи були екзогенними, а $з$ цього періоду набувають ендогенних ознак.

У статті проаналізовано історію та економічне підгрунтя промислових криз у французькій версії досліджень Туган-Барановського. Також здійснено критичний огляд інтелектуальної спадщини Туган-Барановського, яка суттєво вплинула на дослідження його франкомовних послідовників, а саме Лескура, Афталіона, Робертсона та Бунятяна; проведено паралелі між Туган-Барановським та Кейнсом і Марксом. Теорію циклів Туган-Барановського можна оцінити та глибоко зрозуміти завдяки двом важливим економічним та політичним подіям: перехід від реального до монетарного циклів у міжвоєнний період та пожвавлення реальних ділових циклів під час Нової класичної економіки у 1980-х роках, що знову є актуальним у контексті поточної Великої рецесії локдаунів.

Ключові слова: історія макроекономічного аналізу, промислові кризи, реальні цикли, українське наукове мислення.

Матеріал надійшов 12.05.2021

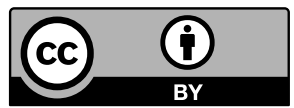

Creative Commons Attribution 4.0 International License (CC BY 4.0) 